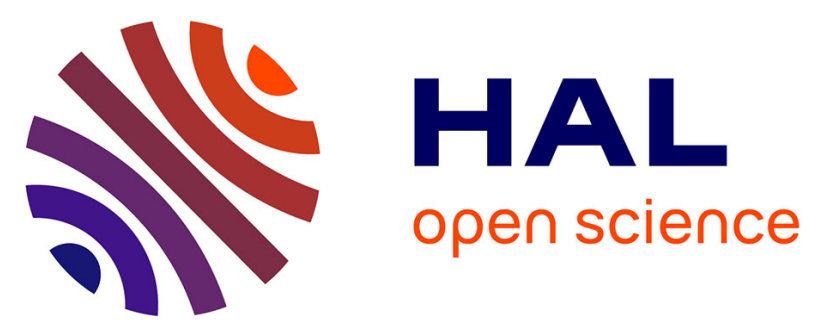

\title{
Within-population variability in architectural traits and suitability to forestry conditions in Nothofagus nervosa (= N. alpina; Nothofagaceae)
}

Javier Puntieri, Javier Grosfeld, Luis Tejera, Víctor Mondino, Leonardo Gallo

\section{- To cite this version:}

Javier Puntieri, Javier Grosfeld, Luis Tejera, Víctor Mondino, Leonardo Gallo. Within-population variability in architectural traits and suitability to forestry conditions in Nothofagus nervosa (= N. alpina; Nothofagaceae). Annals of Forest Science, 2013, 70 (5), pp.471-479. 10.1007/s13595-013-02868. hal-01201496

\author{
HAL Id: hal-01201496 \\ https://hal.science/hal-01201496
}

Submitted on 17 Sep 2015

HAL is a multi-disciplinary open access archive for the deposit and dissemination of scientific research documents, whether they are published or not. The documents may come from teaching and research institutions in France or abroad, or from public or private research centers.
L'archive ouverte pluridisciplinaire HAL, est destinée au dépôt et à la diffusion de documents scientifiques de niveau recherche, publiés ou non, émanant des établissements d'enseignement et de recherche français ou étrangers, des laboratoires publics ou privés. 


\title{
Within-population variability in architectural traits and suitability to forestry conditions in Nothofagus nervosa (= N. alpina; Nothofagaceae)
}

\author{
Javier Puntieri • Javier Grosfeld • Luis Tejera • \\ Víctor Mondino • Leonardo Gallo
}

Received: 26 November 2012 / Accepted: 31 March 2013 /Published online: 19 April 2013

(C) INRA and Springer-Verlag France 2013

\begin{abstract}
- Context There is evidence that Nothofagus nervosa $(=N$. alpina $)$ is suitable for timber production in temperate regions due to its wood quality and fast growth. However, high intra-specific variability in the architectural traits of this species limits its usefulness.

- Aims This study was aimed at evaluating intra-specific variability in the architecture of $N$. nervosa trees at the population level, with emphasis on traits related to the suitability of trees for timber production.

- Methods The size of 13-year-old trees installed in an experimental field population and the extent of differentiation between trunk and branches were compared among families (trees derived from different mother trees).

- Results The large majority of trees exhibited architectural features indicative of high suitability for timber production: clear differentiation between trunk and main branches and few occurrences of permanent trunk forks, apex deaths, and
\end{abstract}

Handling Editor: Erwin Dreyer

Contribution of the co-authors J. Puntieri: manuscript writing, data analyses, field work, field-work supervision

J. Grosfeld: field work, field-work supervision

L. Tejera: experiment design and maintenance

V. Mondino: experiment design and maintenance, field work

L. Gallo: coordination of research project, experiment design

J. Puntieri $\cdot$ J. Grosfeld

INIBIOMA, Universidad Nacional del Comahue and Consejo

Nacional de Investigaciones Científicas y Técnicas, Quintral 1250,

8400 Bariloche, Argentina

J. Puntieri $(\bowtie)$

Universidad Nacional de Río Negro, Viedma,

Río Negro Province, Argentina

e-mail: jgpuntieri@gmail.com

L. Tejera $\cdot$ V. Mondino $\cdot$ L. Gallo

INTA Bariloche, Bariloche, Argentina sylleptic branching. Trees belonging to different families differed in height and trunk diameter. Micro-environmental conditions had a very significant effect on most architectural traits, including the trunk differentiation.

- Conclusions N. nervosa emerges as a suitable option for timber production in temperate regions. Trunk growth seems to be under both environmental and genetic control in this species.

Keywords Architecture $\cdot$ Domestication $\cdot$ Hierarchical structure $\cdot$ Growth unit $\cdot$ Intra-specific variability $\cdot$ Trunk differentiation

\section{Introduction}

The aerial structure or architecture of plants would have evolved in response to different selective pressures. A classical example of the adaptive importance of plant architecture is provided by the competitive advantage of height growth in crowded and/or understory populations (e.g., Aiba and Nakashizuka 2007). In the case of trees, the differentiation between a vertical axis (the trunk) and its lateral derivations (trunk branches) would be a characteristic favored by natural selection in crowded populations (King 1981, 1998) as well as by artificial selection in forestries where the production of long and straight logs is prioritized. Those architectures in which trunk and branches are clearly differentiated from each other have been described as strongly hierarchical, as opposed to those in which all axes are alike (Edelin 1991; Ishii et al. 2007; Normand et al. 2009). There is no general agreement about the way of evaluating the degree of hierarchical strength of tree architecture; computing the ratio between a measure of trunk size (e.g., length and diameter) and an equivalent measure of its branches proved useful in this regards (Valladares and Niinemets 2007; Puntieri and Ghirardi 2010). 
Whether a tree develops or not a strongly hierarchical architecture at an early developmental stage depends largely upon genetic (including ontogenetic) factors, as comprehensively described by F. Hallé and his co-workers (Hallé et al. 1978; Barthélémy and Caraglio 2007). Intra-specific architectural variations in trees due to environmental and genetic factors have been acknowledged and may be studied experimentally by comparing plants of known geographical and genetic background. However, few studies were aimed at disentangling these two sources of variation (e.g., Barthélémy et al. 1999a; Louarn et al. 2007), partly because of the long time periods needed for the expression of architectural variability in trees. A better knowledge about intraspecific variation in architectural traits may not only improve our understanding of the evolution of plant architecture but also help in setting criteria for the selection of mother trees with wood-production purposes (Neale and Kremer 2011).

In temperate and cold regions, conifers, and especially Pinus species, comply with the strongly hierarchical architecture suitable for timber production and occupy a large proportion of forested lands (Brockerhoff et al. 2008; FAO 2012). However, both the negative impacts of pine forestries on both soil properties and biodiversity (Huber et al. 2010; Pijut et al. 2011; Simberloff et al. 2010), and the likelihood of broad-scale falls in timber production as a consequence of climatic changes (Sykes and Prentice 1996), have stimulated the diversification of forestries in some countries (e.g., Hardcastle 2006). Several South American Nothofagus species, among them Nothofagus nervosa $(=N$. alpina $=N$. procera, Nothofagaceae $)$, have been regarded as good alternatives to pines, as they combine reasonable yearly height growth, a hierarchical architecture at juvenile stages, and high timber quality (Stewart 1979; Destremau 1988). The connection between intra-specific architectural variability and the geographical or genetic background of trees has been evaluated for the related species Nothofagus obliqua (Puntieri et al. 2006, 2007) but not for $N$. nervosa. In the present study, we investigated withinpopulation architectural variability in 13-year-old $N$. nervosa trees established in an experimental population.

\section{Materials and methods}

\subsection{Experimental design}

In 1997 (a masting year for $N$. nervosa), N. nervosa seeds derived from open pollination were collected by hand from 27 randomly selected trees within 50 ha of the Tromen Lake area of Lanín National Park, Argentina $\left(39^{\circ} 34^{\prime} \mathrm{S}, 71^{\circ} 26^{\prime} \mathrm{W}\right.$, altitude $1,110 \mathrm{~m}$ ). Seedlings were grown in a tree nursery (Vivero de Genética Forestal, INTA Bariloche, Argentina) for 2 years. In 1999, the 2-year-old saplings were planted in an area of approximately 1 ha belonging to INTA (Estación

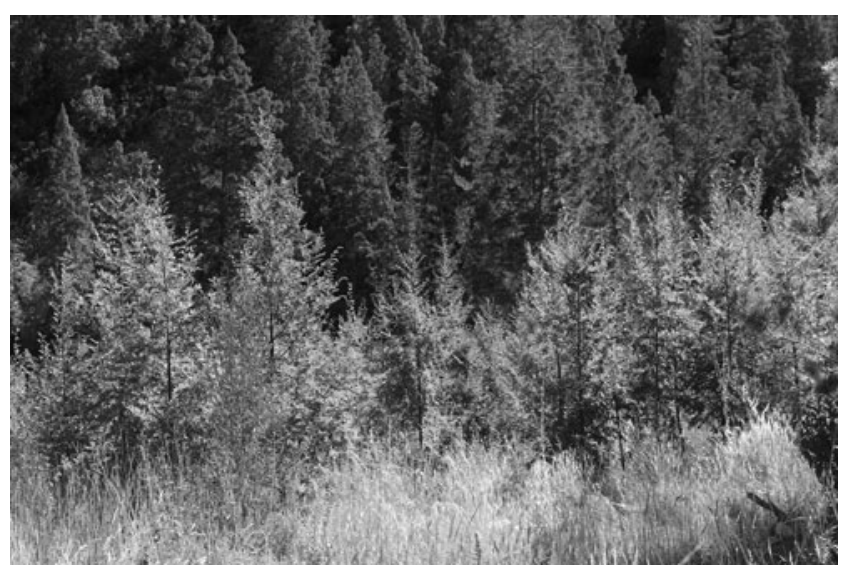

Fig. 1 Experimental population of 13-year-old Nothofagus nervosa trees (those with light foliage right at the foreground) at INTA's Estación Agroforestal Trevelin, Argentina. The darker trees at the background belong to the native conifer Austrocedrus chilensis

Agroforestal Trevelin, $43^{\circ} 06^{\prime} 43^{\prime \prime} \mathrm{S}, 71^{\circ} 33^{\prime} 43^{\prime \prime} \mathrm{W}$, altitude $456 \mathrm{~m}$ ), about $390 \mathrm{~km}$ south of the seed-source trees (Fig. 1). This area had a dense cover of woody plants, dominated by Diostea juncea, Buddleja globosa, Aristotelia chilensis (native species), and Betula pendula (exotic species) after a fire that occurred in 1987. Vegetation thinning was applied to provide an intermediate level of plant cover and facilitate the establishment of the $N$. nervosa saplings (Donoso et al. 2006). $N$. nervosa saplings were organized in 21 blocks, each integrated by 32 individuals arranged in four east-west-oriented rows and eight north-south-oriented lines. The minimum distance between saplings within each block was $1 \mathrm{~m}$. Blocks were distant about $7 \mathrm{~m}$ from each other and organized along five east-west-oriented lines, with a minimum distance between lines of about $10 \mathrm{~m}$. The vegetation surrounding the N. nervosa samplings was cut in 2001 and 2007.

Trees derived from seeds collected from the same mother tree will be referred to as a family. Each block of the experimental population was integrated with trees belonging to different families. Not all families were represented in each block, partly because a few trees were available for some of the families from start, and partly because several trees died or were severely damaged during or after the transplant to the experimental area. N. nervosa trees derived from other natural populations of Argentina and grown at the same time and under the same conditions as those of the 27 families from the Tromen Lake area were included in order to complete the blocks and generate a more homogenous environment. In the long term, this design was aimed at providing, after future events of selection and thinning, a population of seed-source trees of known origin and family. All trees, except those with serious damage to the trunk during the transplant, were measured in March 2010. Data were obtained for 276 trees from the 27 families of the Tromen Lake area. 


\subsection{Measured traits}

For each tree in the experiment, the annual growth units conforming the trunk were identified through the scars left by cataphylls and branches on the stem (Barthélémy et al. 1999b; Puntieri and Ghirardi 2010), and one 4-year-old main branch was selected (Fig. 2). We selected 4-year-old main branches for two reasons: these branches were at a stage of vigorous growth and were not subjected to severe shading from higher branches of the same tree or from main branches of neighbor trees. In all cases, the selected main branch was among the longest and thickest branches of the tree. Each tree was evaluated at three levels: (1) entire treeheight and basal diameter of the trunk; (2) 4-year growthlength, basal diameter, and number of nodes of the 4-yearold main branch, and length growth of the trunk in the four most recent years; and (3) last-year growth-length, basal diameter, and number of nodes of the most recently extended growth unit of the trunk and the 4-year-old main branch. Trunk diameters were measured with an increment tape, whereas the diameters of the main branch and those of the growth units were measured with digital calipers. Tree heights were measured with a graduated pole. The number of nodes of growth units was obtained by counting the green leaves or the scars

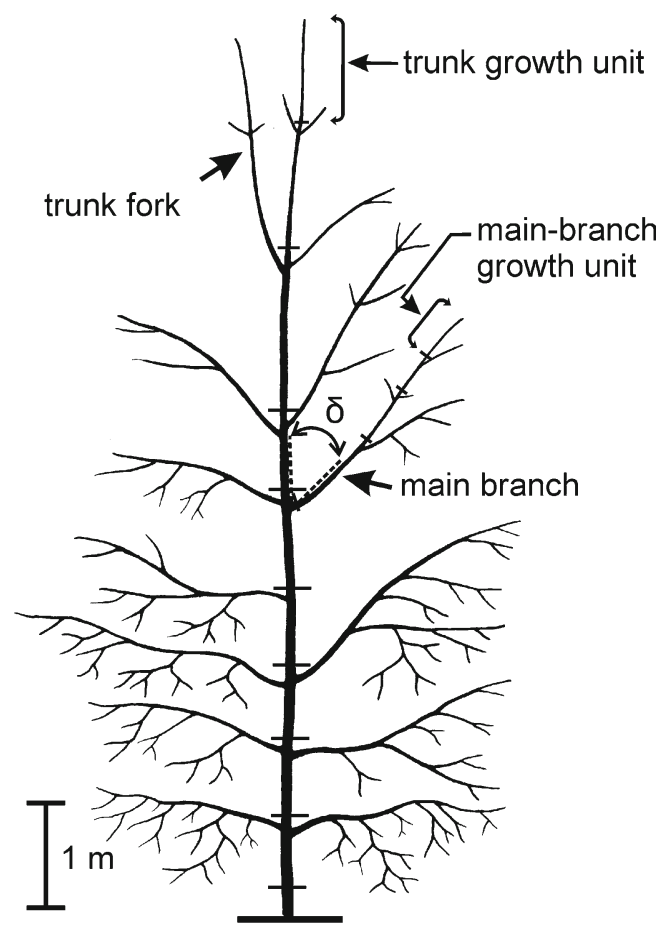

Fig. 2 Diagrammatic representation of a Nothofagus nervosa tree similar to those included in the present study. The limits between successive annual growth units developed on the trunk and on a 4year-old main branch are marked by thick short lines. The most distal growth unit of the trunk and the 4-year-old main branch are marked with brackets. The angle $(\delta)$ formed between the trunk and a 4-year-old main branch is indicated with dotted lines and an arc left by fallen green leaves on the stem. In this, like in other species of Nothofagus, the number of cataphylls (blade-less leaves at basal nodes) of each growth unit is relatively constant (Barthélémy et al. 1999b). Since at least some of the trees under survey were meant to be future seed sources, destructive measures were avoided. Ladders were employed to have access to the distal end of the trunk and its branches. For the tallest trees, the proximal end of the most recently extended trunk growth unit could not be reached, so that the basal diameter of this growth unit was missing. In such cases, an estimation of the length of this growth unit was obtained using the graduated pole and binoculars. Other missing values were due to the damage caused to growth units by unknown factors (probably insects) which prevented unmistaken evaluations of the numbers of nodes and the basal diameter of growth units.

Slenderness (stem length/basal diameter) was computed for the entire trunk, the most recent trunk growth unit, and the most recent main-branch growth unit, and internode length (stem length/number of nodes) was computed for the most recent growth unit of both the trunk and the main branch. Previous studies showed the relevance of these ratios for comparing Nothofagus trees of different provenances and progenies (e.g., Puntieri et al. 2007; Puntieri and Ghirardi 2010).

The hierarchical structure of the trees was evaluated through the following variables. In the first place, the ratios tree height/main-branch length and trunk diameter/main-branch diameter were calculated. Secondly, the angle $(\delta)$ formed between the trunk and the 4-year-old main branch was measured at the base of the branch with a board protractor. Since branches are not straight axes, in registering $\delta$ we took into account the proximal, lignified portion of the branch, which is less likely to vary its orientation over time (Fig. 2). Thirdly, for each tree a measure of trunk differentiation (TD) was derived from the following qualitative traits (Fig. 2): (a) presence/ absence of trunk forking established more than 1 year before the time of measurement, (b) presence/absence of codominance between the most recent trunk growth unit and one or more of the most-recent branches derived from the trunk, (c) terminal or axillary origin of the most recent trunk growth unit, and (d) presence/absence of sylleptic branches on the most recent trunk growth unit. It was considered that a trunk was forked when one of its branches (excluding those extended in the most recent growing season) developed almost vertically (i.e., forming an angle $<25^{\circ}$ with the trunk), and had a length greater than two thirds that of the trunk. Similarly, the most recent trunk growth unit and one of the most recent main branches were regarded as codominant when the following two conditions were met: these two axes formed an angle $<25^{\circ}$ between them, and the length of the main branch was greater than two thirds that of the distal trunk growth unit. A binary code was applied to traits (a) to (d): "0" was assigned to those conditions indicative of low trunk differentiation (trunk forking, distal branches codominant to the trunk, axillary origin of trunk 
growth unit, and presence of sylleptic branches) and "1" to those indicative of high trunk differentiation. By simple addition of these code numbers, TD, ranging from 0 (low differentiation) to 4 (high differentiation), was computed for each tree. Thus, a strongly hierarchical tree architecture would be indicated by high values for tree height/main-branch length, trunk diameter/main-branch diameter, $\delta$ (i.e., with the main branch deviating from the vertical), and TD.

\subsection{Statistical analyses}

Statistical comparisons among families were carried out for trees belonging to the families of the Tromen Lake area represented in the experiment by at least 10 trees each (12 families and 188 trees). In order to evaluate the degree of variability of each trait among families, analysis of variance (ANOVA, GLM for unbalanced designs) was applied for those variables that were normally distributed (Kolmogorov-Smirnov test) and had variance homogeneity (Levene's test; Sokal and Rohlf 1981); some variables were $\log _{\mathrm{e}}$-transformed in order to comply with these prerequisites. The same analysis was applied to $\delta$, in spite of its circular nature, because of the relatively narrow range and its normal distribution of $\delta$.

In each ANOVA, family was included as a random factor, as the families included in the experiment constituted a random sample of Argentinean $N$. nervosa families. The numbers of line (which indicates the east to west position of the tree within each block) and block were included as fixed factors; a preliminary analysis of the data obtained from all trees in the experiment demonstrated a significant correlation between each of these numbers and tree height. The fact that not all families were represented in all blocks and lines prevented us from evaluating interaction terms. The variable TD could not be normalized even after data transformation, so that it was compared among families, blocks, and lines by means of Kruskal-Wallis tests.

The proportion of trees with the maximum possible TD $(=4)$ was compared among the 12 families represented by 10 or more trees, and among blocks and lines by means of $\chi^{2}$ tests. Pearson's correlation coefficients between $\delta$ and TD and all other traits measured on the trees were computed, including all trees belonging to families of the Tromen Lake area included in the experiment $(N=276)$. Since TD was notably deviated from normality, ranked data were used in all correlations involving this variable (Spearman's rank correlation).

All analyses were performed with the $\mathrm{R}$ software (Venables et al. 2012). A $5 \%$ significance level was adopted in all comparisons.

\section{Results}

\subsection{Tree size and architecture}

The $N$. nervosa trees had a mean height above $5 \mathrm{~m}$ and a mean basal trunk diameter of almost $8 \mathrm{~cm}$ (Table 1; Fig. 3a, b). Trunk slenderness was the variable with the lowest $\mathrm{CV}$ among those evaluated in this study. In the last 4 years of growth, the trunk of the trees had increased, on average, about $2.7 \mathrm{~m}$ in height, whereas the length growth of the main branch developed in the same period was about half that length. The entire 4-year-old main branch was, on average, less than one fourth the length and less than one fifth the diameter of the tree trunk. For the most recent growth unit of both trunk and main branch, stem length was more variable than stem diameter and number of nodes (Table 1). The most recent growth unit developed on the tree trunk was, on average, twice as long and almost twice as thick as the most recent growth unit of the main branch; the difference between trunk and main branch regarding the number of nodes of the most recent growth unit was less notable. Mean slenderness was higher for trunk than for main-branch growth units, despite a notable degree of overlapping between both axes. Trunk growth units had longer internodes than main-branch growth units (Table 1).

Main branches deviated in an angle $(\delta)$ between $20^{\circ}$ and $90^{\circ}$ from the vertical trunk in all trees but one (with the branch at $125^{\circ}$ ). In some cases, this branch was growing codominantly with the trunk $\left(\delta<25^{\circ}\right)$. The angle $\delta$ correlated positively with the ratios between tree height and mainbranch length, and between trunk diameter and mainbranch diameter ratio, trunk slenderness, and with the length of the trunk in the four most recent years. $\delta$ correlated negatively with the diameter and length of the entire 4year-old main branch and with the diameter and number of nodes of the most recent main-branch growth unit (Table 2).

TD varied between 2 and 4 for the large majority of trees $(90.4 \%)$, and almost half of the trees (45.9\%) reached the highest possible score (TD=4; Fig. 4). TD correlated positively with the ratios tree height/main-branch length and trunk diameter/main-branch diameter, the number of nodes of the most recent trunk growth unit, the ratio between trunk height growth in the last 4 years and tree height, and trunk height growth in the last 4 years. TD correlated negatively with slenderness, internode length, and stem length of the most recent main-branch growth unit, and with the length of the entire main branch.

\subsection{Comparisons among families, blocks, and lines}

The family affected significantly the variability in tree height and trunk diameter, the ratio between trunk height growth in the four most recent years and tree height, and the number of nodes of the most recent trunk growth unit 
Table 1 Mean, variance (Var.), coefficient of variation (CV), first quartile (Q1), and third quartile (Q3) for each of the variables measured in

Nothofagus nervosa trees of the Tromen Lake origin developed in the experimental population

The number of trees for which each of these variables was obtained is also indicated $(N)$

\begin{tabular}{|c|c|c|c|c|c|c|}
\hline Variable & Mean & Var. & $\mathrm{CV}(\%)$ & Q1 & Q3 & $N$ \\
\hline \multicolumn{7}{|l|}{ Tree } \\
\hline Tree height (m) & 5.6 & 1.17 & 19.4 & 4.8 & 6.3 & 276 \\
\hline Trunk diameter $(\mathrm{cm})$ & 7.7 & 3.10 & 22.7 & 6.4 & 8.9 & 275 \\
\hline Trunk slenderness $(\mathrm{m} / \mathrm{cm})$ & 0.7 & 0.01 & 15.1 & 0.7 & 0.8 & 275 \\
\hline \multicolumn{7}{|l|}{ Four-year growth of trunk } \\
\hline Stem length (m) & 2.7 & 0.41 & 23.2 & 2.3 & 3.1 & 276 \\
\hline \multicolumn{7}{|l|}{ Four-year growth of main branch } \\
\hline Stem length (m) & 1.3 & 0.10 & 25.2 & 1.1 & 1.5 & 276 \\
\hline Stem diameter $(\mathrm{cm})$ & 1.4 & 0.14 & 26.3 & 1.2 & 1.7 & 276 \\
\hline \multicolumn{7}{|l|}{ Last-year growth units of the trunk } \\
\hline Stem length (m) & 0.76 & 0.076 & 36.2 & 0.55 & 0.95 & 276 \\
\hline Stem diameter $(\mathrm{mm})$ & 7.8 & 4.28 & 26.5 & 6.5 & 9.0 & 142 \\
\hline Stem nodes & 20 & 22.0 & 23.7 & 17 & 23 & 276 \\
\hline Stem slenderness $(\mathrm{m} / \mathrm{mm} \times 100)$ & 9.0 & 6.36 & 27.9 & 7.4 & 10.6 & 142 \\
\hline Internode length (cm/node) & 3.8 & 1.12 & 27.7 & 3.2 & 4.5 & 276 \\
\hline \multicolumn{7}{|l|}{ Last-year growth units of main branch } \\
\hline Stem length $(\mathrm{m})$ & 0.32 & 0.017 & 40.4 & 0.22 & 0.40 & 275 \\
\hline Stem diameter $(\mathrm{mm})$ & 4.2 & 1.08 & 24.7 & 3.6 & 4.8 & 274 \\
\hline Stem nodes & 14 & 12.1 & 25.2 & 12 & 16 & 274 \\
\hline Stem slenderness $(\mathrm{m} / \mathrm{mm} \times 100)$ & 7.4 & 4.81 & 29.5 & 5.9 & 8.8 & 274 \\
\hline Internode length (cm/node) & 2.2 & 0.39 & 27.8 & 1.9 & 2.6 & 274 \\
\hline \multicolumn{7}{|l|}{ Hierarchical structure } \\
\hline Tree height/stem length of main branch & 4.5 & 1.54 & 27.4 & 3.7 & 5.0 & 276 \\
\hline Trunk diameter/stem diameter of main branch & 5.6 & 1.96 & 24.9 & 4.7 & 6.2 & 275 \\
\hline$\delta\left({ }^{\circ}\right)$ & 57 & 227.7 & 26.6 & 45 & 65 & 276 \\
\hline
\end{tabular}

(Table 3; Fig. 3). The families with the longest and thickest trunks were not those with the highest trunk growth in recent years (Fig. 3). The block affected significantly all variables but main-branch length, and the length, slenderness, and internode length of the most recent trunk growth unit (Table 3). The line within the block where a tree was
Fig. 3 Tree height (a), basal diameter (b), height growth in the last 4 years relative to total tree height (c), and number of nodes of the most recent trunk growth unit (GU; d) of Nothofagus nervosa trees grown in an experimental population and belonging to 12 families of the same natural population. Mean \pm 1 SE are shown. Families are rank-ordered by increasing tree height
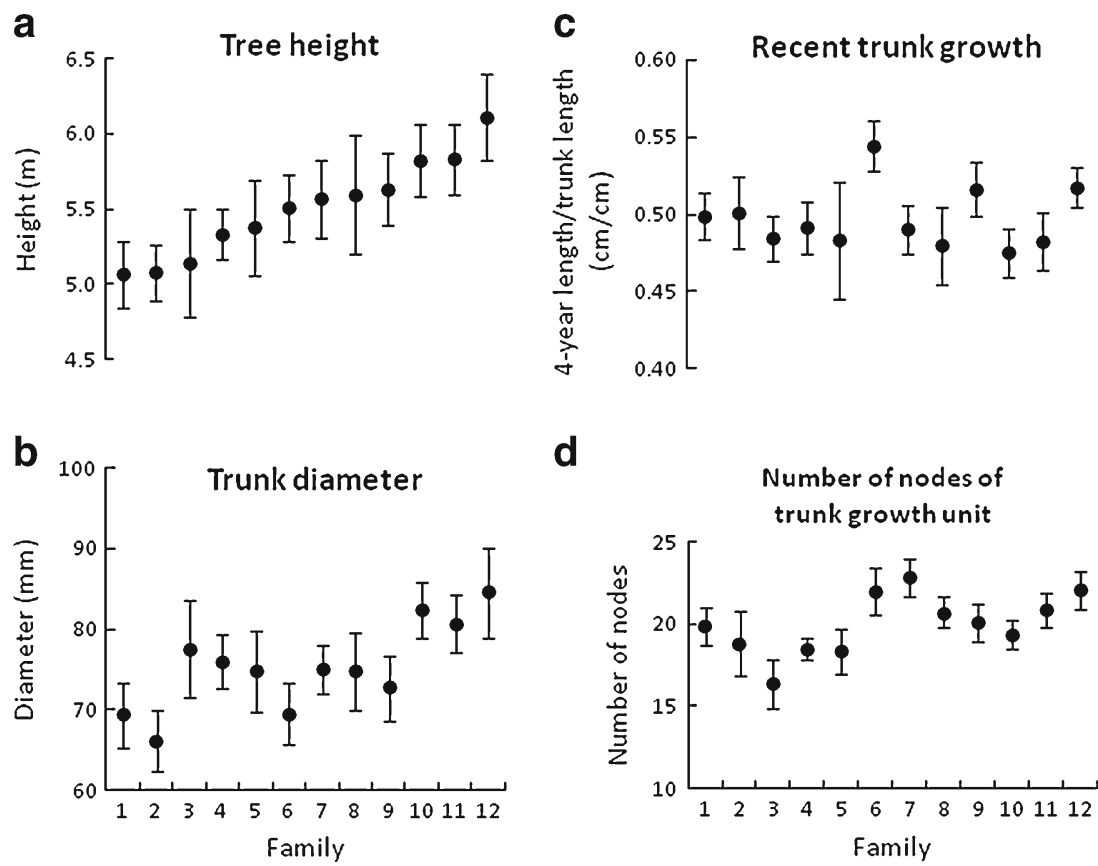

d

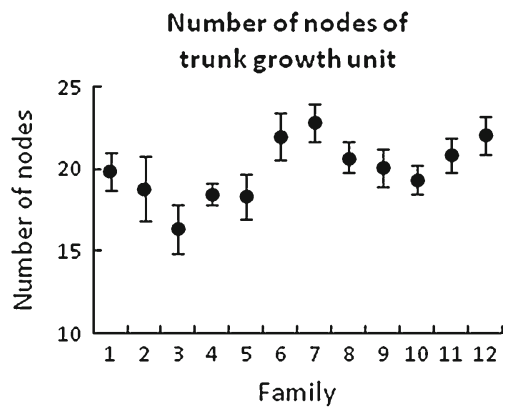


Table 2 Pearson's correlation coefficients $(R)$ and their significance levels $(p)$ for the relationships between the angle formed between the trunk and the 4-year-old main branch $(\delta)$ and the measure of trunk differentiation (TD) and other morpho-architectural traits assessed in this study for 276 Nothofagus nervosa trees of the Tromen Lake area of Argentina
${ }^{*} p<0.05, * * p<0.01$,

$* * * p<0.001$, ns: $p>0.05$.

In the case of TD, Spearman's correlations on ranked data were computed as TD deviated from normality

\begin{tabular}{|c|c|c|c|c|}
\hline \multirow[t]{2}{*}{ Variable } & \multicolumn{2}{|l|}{$\delta$} & \multicolumn{2}{|l|}{$\mathrm{TD}$} \\
\hline & $R$ & $p$ & $R$ & $p$ \\
\hline \multicolumn{5}{|l|}{ Tree } \\
\hline Tree height & 0.116 & ns & 0.069 & ns \\
\hline Trunk diameter & -0.071 & ns & 0.030 & ns \\
\hline Trunk slenderness & 0.244 & $* * *$ & 0.065 & ns \\
\hline \multicolumn{5}{|l|}{ Four-year growth of trunk } \\
\hline Stem length & 0.131 & $*$ & 0.147 & * \\
\hline Stem length/tree height & 0.042 & ns & 0.161 & $* *$ \\
\hline \multicolumn{5}{|l|}{ Four-year growth of main branch } \\
\hline Stem length & -0.209 & $* * *$ & -0.110 & $\mathrm{~ns}$ \\
\hline Stem diameter & -0.310 & $* * *$ & -0.074 & ns \\
\hline \multicolumn{5}{|l|}{ Last-year growth units of trunk } \\
\hline Stem length & 0.011 & ns & 0.072 & ns \\
\hline Stem diameter & -0.034 & ns & 0.094 & ns \\
\hline Stem nodes & -0.011 & ns & 0.189 & $* *$ \\
\hline Stem slenderness & -0.104 & ns & -0.003 & ns \\
\hline Internode length & -0.001 & ns & -0.059 & ns \\
\hline \multicolumn{5}{|l|}{ Last-year growth units of main branch } \\
\hline Stem length & -0.102 & ns & -0.152 & * \\
\hline Stem diameter & -0.122 & $*$ & -0.040 & ns \\
\hline Stem nodes & -0.109 & $*$ & -0.109 & ns \\
\hline Stem slenderness & -0.068 & ns & -0.209 & $* * *$ \\
\hline Internode length & -0.089 & ns & -0.114 & ns \\
\hline \multicolumn{5}{|l|}{ Hierarchical structure } \\
\hline Tree height/stem length of main branch & 0.327 & $* * *$ & 0.197 & $* *$ \\
\hline Trunk diameter/stem diameter of main branch & 0.266 & $* * *$ & 0.121 & $*$ \\
\hline$\delta$ & & & 0.077 & $\mathrm{~ns}$ \\
\hline
\end{tabular}

planted affected significantly the variables tree height, trunk slenderness, the length and diameter of the entire main branch and of the most-recent main-branch growth unit, and the ratio between tree height and main-branch length.

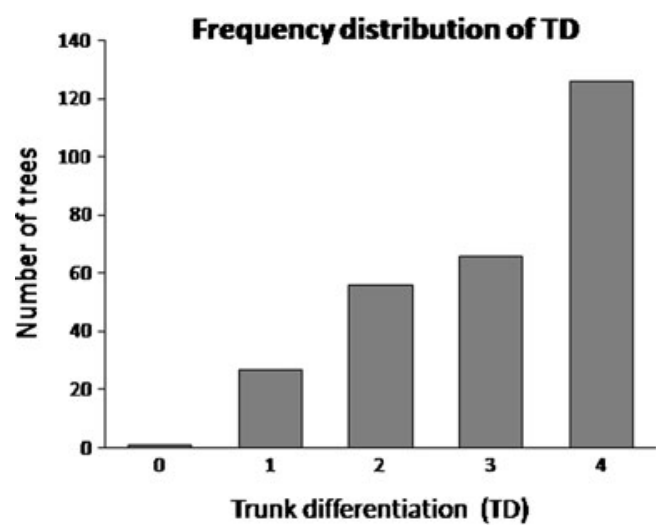

Fig. 4 Frequency distribution of trunk differentiation (TD), computed by taking four qualitative traits into account: (1) presence/absence of trunk forking, (2) presence/absence of codominance, (3) terminal or axillary origin of the most recent trunk growth unit, and (4) presence/ absence of sylleptic branches (see text for more details)
The proportion of trees with the highest possible TD $(=4)$ did not differ among families $\left(\chi^{2}=4.8, p>0.1\right)$ or lines $\left(\chi^{2}=\right.$ $3.8, p>0.1)$, but varied significantly among blocks $\left(\chi^{2}=38.8\right.$, $p<0.01)$. In 10 out of 21 blocks, a TD $=4$ was found in at least half of the trees belonging to the families represented by 10 or more trees.

\section{Discussion}

\subsection{Nothofagus trees for timber production}

For more than one century, South American Nothofagus species, and $N$. nervosa in particular, have been regarded as good alternatives to pines for timber production in temperate regions (Murray et al. 1986). The present study complies with this view. The 13-year-old trees studied here had maintained, at least during the last four growth seasons surveyed, yearly height increments of more than $0.7 \mathrm{~m}$, which is consistent with their juvenile-adult developmental stage (Salas and García 2006; Stecconi et al. 2010), and comparable with the height 
Table 3 Results of the comparisons among families (random factor), experimental blocks, and the line within each block (fixed factors) for variables measured on Nothofagus nervosa trees
$* p<0.05, * * p<0.01$ $* * * p<0.001$, ns: $p>0.05$.

Total degrees of freedom $(d f)$, the value of Fisher's $F$ statistic, and the corresponding error probability $(p)$ are indicated for all variables except trunk differentiation (TD, non-normally distributed), which was compared among families, blocks, and lines with Kruskal-Wallis tests. For this variable, the number of trees included in the comparison is indicated instead of $d f$. Values in italics indicate that the variable was $\log _{\mathrm{e}}$-transformed before analysis

\begin{tabular}{|c|c|c|c|c|c|c|c|}
\hline \multirow[b]{2}{*}{ Variable } & \multirow[b]{2}{*}{$d f$} & \multicolumn{2}{|c|}{ Family } & \multicolumn{2}{|c|}{ Block } & \multicolumn{2}{|c|}{ Line } \\
\hline & & $F$ & $p$ & $F$ & $p$ & $F$ & $p$ \\
\hline \multicolumn{8}{|l|}{ Tree } \\
\hline Tree height & 187 & 2.3 & $* *$ & 6.6 & $* * *$ & 4.9 & $* * *$ \\
\hline Trunk diameter & 186 & 2.5 & $* *$ & 3.9 & $* * *$ & 1.6 & ns \\
\hline Trunk slenderness & 186 & 1.5 & ns & 2.9 & $* * *$ & 2.2 & * \\
\hline \multicolumn{8}{|l|}{ Four-year growth of trunk } \\
\hline Stem length & 187 & 1.2 & ns & 4.2 & $* * *$ & 1.5 & ns \\
\hline Stem length/tree height & 187 & 2.4 & $* *$ & 4.0 & $* * *$ & 0.9 & $n s$ \\
\hline \multicolumn{8}{|l|}{ Four-year growth of main branch } \\
\hline Stem length & 187 & 0.7 & $\mathrm{~ns}$ & 1.3 & ns & 2.5 & * \\
\hline Stem diameter & 187 & 1.3 & ns & 1.7 & * & 2.4 & * \\
\hline \multicolumn{8}{|l|}{ Last-year growth of trunk } \\
\hline Stem length & 187 & 1.2 & ns & 1.6 & $\mathrm{~ns}$ & 1.2 & ns \\
\hline Stem diameter & 96 & 1.1 & ns & 2.5 & $* *$ & 2.0 & ns \\
\hline Stem nodes & 187 & 2.3 & * & 1.9 & * & 1.7 & ns \\
\hline Stem slenderness & 96 & 0.6 & ns & 0.9 & $\mathrm{~ns}$ & 0.5 & ns \\
\hline Internode length & 187 & 0.6 & ns & 0.9 & ns & 0.3 & ns \\
\hline \multicolumn{8}{|l|}{ Last-year growth of main branch } \\
\hline Stem length & 187 & 1.3 & ns & 2.7 & $* * *$ & 2.6 & * \\
\hline Stem diameter & 186 & 1.1 & ns & 1.9 & * & 3.3 & $* *$ \\
\hline Stem nodes & 187 & 1.2 & ns & 2.3 & ** & 1.5 & ns \\
\hline Stem slenderness & 186 & 1.0 & ns & 2.3 & ** & 0.8 & ns \\
\hline Internode length & 149 & 1.2 & ns & 2.0 & * & 1.9 & ns \\
\hline \multicolumn{8}{|l|}{ Hierarchical structure } \\
\hline Tree height/stem length of main branch & 187 & 0.9 & $n s$ & 3.0 & $* * *$ & 2.5 & * \\
\hline Trunk diameter/stem diameter of main branch & 186 & 1.4 & $n s$ & 3.2 & $* * *$ & 1.5 & $n s$ \\
\hline$\delta$ & 187 & 1.1 & ns & 2.8 & $* * *$ & 1.2 & ns \\
\hline $\mathrm{TD}$ & 188 & 5.3 & $\mathrm{~ns}$ & 35.3 & $*$ & 4.3 & ns \\
\hline
\end{tabular}

growth of temperate pines at the same stage (Kozlowski 1964). Coarse observations of Nothofagus trees growing in their native forests may suggest that some traits undesirable for timber production such as feeble trunk differentiation, sympodial branching, persistent trunk forking, and sylleptic branching (i.e., low trunk differentiation) are highly frequent (see Barthélémy et al. 1999b). However, none of these features seems to be prevalent, and their combined occurrence appears to be highly unlikely in young $N$. nervosa trees of the Tromen Lake provenance of Argentina. The other South American Nothofagus species valued for timber production, Nothofagus pumilio (e.g., Martínez Pastur et al. 2007) and N. obliqua (e.g., Salas and García 2006), may reach yearly increments in height and diameter comparable with those recorded here for N. nervosa (Salas and García 2006; Puntieri et al. 2007; Stecconi et al. 2010), but none of them combines a clear differentiation of the trunk from its main branches with the low occurrence of sylleptic branches. The present results, though limited due to the local scale of the experimental population, are encouraging, taking into account that no phenotypical selection of $N$. nervosa trees was performed at the stages of seed collection or experimental setup. Besides, a successful population establishment was achieved at a site cooler and drier than those inhabited naturally by $N$. nervosa (Conti 1998).

4.2 Effects of environmental factors on the architecture of $N$. nervosa trees

In the present study, and despite the relatively low surface occupied by this experiment ( $1 \mathrm{ha}$ ), the block where a tree was planted had, unexpectedly, a larger influence than the family on all traits that were analyzed. Moreover, the block had a significant effect $(p<0.05)$ on recent trunk and main-branch growth as well as on the hierarchical structure of trees, whereas the family had no or little effect on these variables. The position of each tree along the east-west gradient within a block also affected some tree traits. In general terms, trees located toward the eastern end of the experimental area and toward the eastern end of each block tended to be shorter (up to $1 \mathrm{~m}$ on average) 
than those at the western end of either the experimental area or the block. Gradients in soil structure and/or incident light could have been involved in these differences (see Amer 2003; Mäkinen and Hein 2006). Since the size of the most recent trunk growth unit was not affected by tree position in the block, it may be hypothesized that variability in tree height was more influenced by conditions at the time of establishment and tended to stabilize or decrease within each block as trees got older.

\subsection{The architecture of $N$. nervosa and its genetic variability}

Intra-specific variability must be regarded as a resource upon which artificial selection may be applied in an early step towards domestication (Leakey and Tchoundjeu 2001; Gallo et al. 2006). So far, studies aimed at evaluating intra-specific variability in the structure of Nothofagus trees and their adequacy to different climatic conditions have accounted for provenance (Deans et al. 1992; Puntieri et al. 2006) rather than family effects (but see Puntieri et al. 2007). The main objective of the present study was to assess the extent of structural variability among young $N$. nervosa trees derived from trees of a single natural population, with the focus on morpho-architectural traits regarded as relevant in forestry situations. One of the main outcomes of the present study is that the selection of a particular N. nervosa tree as seed source (family effect in this study) may influence the height and trunk diameter of the trees derived from these seeds. Both traits are easily measurable and useful when evaluating the suitability of trees for timber production. A significant difference among families was also found concerning the relative height increment in the last 4 years. This may indicate that trees of different genetic origin within a population could have different rates of decrease in trunk vigor with age, suggesting that this variable would not affect individual fitness at the population level. An alternative explanation could be that the factors that determine geographical isolation of tree populations in north-western Patagonia-i.e., volcanic events and glaciers (e.g., see Marchelli and Gallo 2006; Millerón et al. 2008; Pastorino et al. 2009) —would not necessarily imply genetic isolation, perhaps due to long-distance pollen dispersal by wind.

A general survey on morphological and architectural traits of Nothofagus trees from South America concluded that these species have architectural resemblances with Fagus species, which belong to the related Fagaceae family (Barthélémy et al. 1999b). According to Hallé et al. (1978), Fagus species fit Troll's architectural model, in which the trunk is constructed through a succession of plagiotropic axes that approach verticality during secondary growth. Many species that follow this model have the tendency to develop, from early growth stages, an umbrella-like crown (Hallé et al. 1978). Among South American Nothofagus species, $N$. pumilio is the one that most closely matches this umbrella-like expression of Troll's model (Stecconi et al. 2010). N. nervosa, on the contrary, develops a predominantly vertical and monopodial trunk with tiered branches from very early growth stages, and thus may be approximated to Massart's or Rauh's model, depending on whether main branches are considered, respectively, plagiotropic or orthotropic axes. In these two models, trunk and main branches may be clearly differentiated, as in the case of many conifers as well as in Quercus spp. (also in the related Fagaceae family; Hallé et al. 1978). In the present study, the angle formed between trunk and main branches in $N$. nervosa trees varied widely and was found to be related to tree architecture: trees with wider-angled (more horizontal) main branches had developed a longer trunk segment in the four most recent years and a more slender trunk than trees with narrower-angled (more vertical) main branches. In $N$. nervosa, main branches arise at the distal end of trunk growth units and initiate their development as slanted to almost vertical codominant axes (Barthélémy et al. 1999b). The results obtained here suggest that the persistence over several years of main branches in a position codominant to the trunk would favor their own growth and reduce trunk height growth. Depending on whether main branches follow, as they grow, a narrow angle with the trunk or approach horizontality, $N$. nervosa trees could be included in Rauh's or Massart's models. It is interesting to notice that this architectural variability may be expressed within a population of trees.

\subsection{Concluding remarks}

When assessing architectural traits at the juvenile-adult growth stage, $N$. nervosa appears to be more suitable than other South American Nothofagus species and a good option to pine trees for timber production in temperate regions. Even before any kind of phenotypic or genotypic selection is applied, the architecture of $N$. nervosa trees is adequate for timber production and those traits that may be considered detrimental (such as early trunk forking) could be treated with ease. Trunk height and diameter would depend somehow on the genetic background of $N$. nervosa trees, which provides some space for artificial selection. Environmental factors, however, seem to play a key role in defining the size of the major axes and the hierarchical structure of young $N$. nervosa trees.

Acknowledgments The authors thank Amaru Magnin, Cristian Torres, and Santiago Quiroga for their assistance in field work.

Funding This work was supported by the Instituto Nacional de Tecnología Agropecuaria (PNFOR4232) and the Consejo Nacional de Investigaciones Científicas y Técnicas (PIP 11220080101026), Argentina.

\section{References}

Aiba N, Nakashizuka T (2007) Differences in the dry-mass cost of sapling vertical growth among 56 woody species co-occurring in a Bornean tropical rain forest. Func Ecol 21:41-49 
Amer C (2003) Growth and biomass partitioning of Fagus sylvatica L. and Quercus robur L. seedlings in response to shading and small changes in the R/FR-ratio of radiation. Ann For Sci 60:163-171

Barthélémy D, Caraglio Y (2007) Plant architecture: a dynamic, multilevel and comprehensive approach to plant form, structure and ontogeny. Ann Bot 99:375-407

Barthélémy D, Grosfeld J, Bouroulet-Hallard F, Ducatillion C (1999a) Biología, crecimiento y desarrollo. In: Teissier du Cros E (ed) Los cipreses. Un manual práctico. Studio Leonardo, Florence, pp 27-33

Barthélémy D, Puntieri JG, Brion C, Raffaele E, Marino J, Martinez P (1999b) Morfología de las unidades estructurales y modo de desarrollo básico de especies Patagónicas de Nothofagus (Fagaceae). Bol Soc Argent Bot 34:29-38

Brockerhoff EG, Jactel H, Parrotta JA, Quine CP, Sayer J (2008) Plantation forests and biodiversity: oxymoron or opportunity? Biodivers Conserv 17:925-951

Conti HA (1998) Características climáticas de la Patagonia. In: Correa MN (ed) Flora Patagónica VIII (I). Instituto Nacional de Tecnología Agropecuaria, Buenos Aires, pp 31-47

Deans JD, Billington HL, Harvey FJ (1992) Winter frost hardiness of two Chilean provenances of Nothofagus procera in Scotland. Forestry 65:205-212

Destremau DX (1988) Un gisement de bois prometteur: la Patagonie Valdivienne. AFOCEL-ARMEF, Informations-Forêt 1:37-48

Donoso P, Donoso C, Marchelli P, Gallo L, Escobar B (2006) Nothofagus nervosa (Phil.) Dim. et Mil., otros nombres científicos usados: Nothofagus alpina, Nothofagus procera, Raulí, Familia: Fagaceae. In: Donoso C (ed) Las especies arbóreas de los bosques templados de Chile y Argentina. Marisa Cuneo Ediciones, Valdivia, pp 448-461

Edelin CL (1991) Nouvelles données sur l'architecture des arbres sympodiaux: le concept de plan d'organisation. In: Edelin C (ed) L'Arbre, Biologie et Développement. Naturalia monspeliensia, Actes du 2ème Colloque International sur l'Arbre, Montpellier, France, Hors-séries A7, pp 127-154

FAO (2012) Forestry Department. Global data on forest plantations resources. http://www.fao.org/docrep/004/Y2316E/y2316e0b.htm

Gallo LA, Marchelli P, Azpilicueta MM, Crego P (2006) The use of genetic markers in Nothofagus especially in raulí and roble. Bosque 27:3-15

Hallé F, Oldeman RAA, Tomlinson P (1978) Tropical trees and forests. An architectural analysis. Springer, Berlin, p 441

Hardcastle PD (2006) A review of the potential impacts of short rotation forestry. Final Report on SRF-LTS International, Edinburgh. http://www.the-tree.org.uk/TreeCultivation\&Uses/Firewood/ firewood.htm

Huber A, Iroumé A, Mohr C, Frêne C (2010) Efecto de plantaciones de Pinus radiata y Eucalyptus globulus sobre el recurso agua en la Cordillera de la Costa de la región del Biobío, Chile. Bosque 31:219-230

Ishii HT, Ford ED, Kennedy MC (2007) Physiological and ecological implications of adaptive reiteration as a mechanism for crown maintenance and longevity. Tree Physiol 27:455-462

King D (1981) Tree dimensions: maximizing the rate of height growth in dense stands. Oecologia 51:351-356

King D (1998) Relationship between crown architecture and branch orientation in rain forest trees. Ann Bot 82:1-7

Kozlowski TT (1964) Shoot growth in woody plants. Bot Rev 30:335-392

Leakey RRB, Tchoundjeu Z (2001) Diversification of tree crops: domestication of companion crops for poverty reduction and environmental services. Exp Agric 37:279-296

Louarn G, Guédon Y, Lecoeur J, Lebon E (2007) Quantitative analysis of the phenotypic variability of shoot architecture in two grapevine (Vitis vinifera) cultivars. Ann Bot 99:425-437
Mäkinen H, Hein S (2006) Effect of wide spacing on increment and branch properties of young Norway spruce. Eur J For Res 125:239-248

Marchelli P, Gallo LA (2006) Multiple ice-age refugia in a southern beech from southern South America as revealed by chloroplast DNA markers. Conserv Genet 7:591-603

Martínez Pastur G, Lencinas MA, Peri PL, Arena M (2007) Photosynthetic plasticity of Nothofagus pumilio seedlings to light intensity and soil moisture. For Ecol Manage 243:274-282

Millerón M, Gallo L, Marchelli P (2008) The effect of volcanism on postglacial migration and seed dispersal. A case study in southern South America. Tree Genet Genomes 4:435-443

Murray MB, Cannell MGR, Sheppard LJ (1986) Frost hardiness of Nothofagus procera and Nothofagus obliqua in Britain. Forestry 59:209-221

Neale DB, Kremer A (2011) Forest tree genomics: growing resources and applications. Nat Rev 12:111-122

Normand F, Pambo Bello AK, Trottier C, Laurie PE (2009) Is axis position within tree architecture a determinant of axis morphology, branching, flowering and fruiting? An essay in mango. Ann Bot 103:1325-1336

Pastorino M, Marchelli P, Milleron M, Soliani C, Gallo L (2009) The effect of different glaciation patterns over the current genetic structure of the southern beech Nothofagus antarctica. Genetica 136:79-88

Pijut PM, Lawson SS, Michler CH (2011) Biotechnological efforts for preserving and enhancing temperate hardwood tree biodiversity, health, and productivity. In Vitro Cell Dev Biol—Plant 47:123-147

Puntieri JG, Ghirardi S (2010) Growth-unit structure in trees: effects of branch category and position on Nothofagus nervosa, N. obliqua and their hybrids (Nothofagaceae). Trees 24:657-665

Puntieri JG, Grosfeld J, Stecconi M, Brion C, Azpilicueta MM, Gallo L (2006) Desarrollo temprano de roble (Nothofagus obliqua): un análisis arquitectural de procedencias de Argentina. Bosque 27:44-51

Puntieri JG, Grosfeld J, Stecconi M, Brion C, Azpilicueta MM, Gallo L, Barthélémy D (2007) Shoot development and dieback in progenies of Nothofagus obliqua. Ann For Sci 64:839-844

Salas C, García O (2006) Modelling height development of mature Nothofagus obliqua. For Ecol Manage 229:1-6

Simberloff D, Nuñez MA, Ledgard NJ, Pauchard A, Richardson DM, Sarasola M, Van Wilgen BW, Zalba SM, Zenni RD, Bustamante R, Peña E, Ziller SR (2010) Spread and impact of introduced conifers in South America: lessons from other southern hemisphere regions. Austral Ecol 35:489-504

Sokal RR, RohlfFJ (1981) Biometry, 2nd edn. Freeman, New York, p 859

Stecconi M, Puntieri JG, Barthélémy D (2010) An architectural approach to the growth forms of Nothofagus pumilio (Nothofagaceae) along an altitudinal gradient. Botany 88:699_ 709

Stewart PJ (1979) Le genre "Nothofagus" et son utilisation dans la sylviculture Britanique. Rev For Fran 31:473-482

Sykes MT, Prentice IC (1996) Climate change, tree species distribution and forest dynamics: a case study in the mixed conifer/northern hardwood zone of Europe. Climatic Change 34:161-177

Valladares F, Niinemets U (2007) The architecture of plant crowns: from design rules to light capture and performance. In: Pugnaire F, Valladares F (eds) Functional plant ecology. Taylor and Francis, New York, pp 101-149

Venables WN, Smith DM, R Core Team (2012) An introduction to R. Notes on R: A Programming Environment for Data Analysis and Graphics. http://cran.r-project.org/doc/manuals/R-intro.pdf 